Article

\title{
One-Pot Hydrothermal Synthesis of Magnetite Prussian Blue Nano-Composites and Their Application to Fabricate Glucose Biosensor
}

\author{
Ezzaldeen Younes Jomma ${ }^{1,2}$ and Shou-Nian Ding ${ }^{1, *}$ \\ 1 School of Chemistry and Chemical Engineering, Southeast University, Nanjing 211189, China; \\ ezzoezzo11@yahoo.com \\ 2 Food Technology Department, Nyala Technological College, Nyala P. O. Box 155, Sudan \\ * Correspondence: snding@seu.edu.cn; Tel./Fax: +86-25-5209-0621
}

Academic Editors: Yu Lei, Ashutosh Tiwari and Hongyun Liu

Received: 7 December 2015; Accepted: 15 February 2016; Published: 18 February 2016

\begin{abstract}
In this work, we presented a simple method to synthesize magnetite Prussian blue nano-composites $\left(\mathrm{Fe}_{3} \mathrm{O}_{4}-\mathrm{PB}\right)$ through one-pot hydrothermal process. Subsequently, the obtained nano-composites were used to fabricate a facile and effective glucose biosensor. The obtained nanoparticles were characterized using transmission electron microscopy, scanning electron microscopy, Fourier-transform infrared spectroscopy, UV-vis absorbance spectroscopy, cyclic voltammetry and chronoamperometry. The resultant $\mathrm{Fe}_{3} \mathrm{O}_{4}-\mathrm{PB}$ nanocomposites have magnetic properties which could easily controlled by an external magnetic field and the electro-catalysis of hydrogen peroxide. Thus, a glucose biosensor based on $\mathrm{Fe}_{3} \mathrm{O}_{4}-\mathrm{PB}$ was successfully fabricated. The biosensor showed super-electrochemical properties toward glucose detection exhibiting fast response time within 3 to $4 \mathrm{~s}$, low detection limit of $0.5 \mu \mathrm{M}$ and wide linear range from $5 \mu \mathrm{M}$ to $1.2 \mathrm{mM}$ with sensitivity of $32 \mu \mathrm{A} \cdot \mathrm{mM}^{-1} \cdot \mathrm{cm}^{-2}$ and good long-term stability.
\end{abstract}

Keywords: magnetite Prussian blue nano-composites; one-pot synthesis; biosensor

\section{Introduction}

Since Clark and Lyons reported their first enzyme electrode for glucose determination in 1962, a tremendous attention has been given to develop electrochemical biosensors via immobilization of the enzymes on an electrode surface [1,2].

Among the electrochemical enzyme biosensors, the glucose biosensors have been developed as commercial clinical devices to monitor the glucose concentration of real time in human being blood. In the mechanism of glucose biosensor, the oxidation of glucose can be catalyzed by glucose oxidase (GOD) in the presence of oxygen to produce gluconic acid and hydrogen peroxide $\left(\mathrm{H}_{2} \mathrm{O}_{2}\right)$ in which the generated $\mathrm{H}_{2} \mathrm{O}_{2}$ can be detected by electrochemical method. However, the detection of $\mathrm{H}_{2} \mathrm{O}_{2}$ at high potential suffers from the oxidation of interferes such as dopamine, uric acid, and ascorbic acid.

Prussian blue (PB) the simplest representative of MHCF family and its different analogues have been utilized worldwide for fabrication of chemical sensors/biosensor as transducers for the reduction of hydrogen peroxide at low applied potential [3,4]. For a glucose biosensor, the generated $\mathrm{H}_{2} \mathrm{O}_{2}$ can be detected by PB which exhibits high activity and selectivity [5]. Despite the attractive properties of $\mathrm{PB}$, the PB films are unstable over long time under neutral or alkaline conditions, which greatly limits their applications in non-acidic solutions [6,7].

The advance in magnetic nanoparticles is their easy separation and purification by an external magnet [8]. Several methods have been used to synthesize magnetic nanoparticles, such 
as co-precipitation, hydrothermal synthesis, thermal decomposition and/or reduction, sol-gel reaction, electrochemical methods, flow injection synthesis and aerosol/vapor [9,10]. Among them, hydrothermal method has the ability to create crystalline phases which are not stable at the melting point. In addition, materials which have a high vapor pressure near their melting points can also be grown by hydrothermal method. Moreover, the hydrothermal method is also particularly suitable for the growth of high-quality nanoparticles while maintaining good control over their composition [11].

Many procedures of synthesis magnetic PB nanoparticles have been reported in the literature. Ge et al. prepared $\mathrm{PB}-\mathrm{Fe}_{3} \mathrm{O}_{4}$ nanoparticles in two step procedure, first synthesized of $\mathrm{Fe}_{3} \mathrm{O}_{4}$ by co-precipitation of $\mathrm{Fe}^{2+}$ and $\mathrm{Fe}^{3+}$ ions in the presence of $\mathrm{NaOH}$ at $80{ }^{\circ} \mathrm{C}$ then the obtained $\mathrm{Fe}_{3} \mathrm{O}_{4}$ particles were suspended in $\mathrm{K}_{3} \mathrm{Fe}(\mathrm{CN})_{6}+\mathrm{FeCl}_{3}+\mathrm{HCl}$ solution under stirring to form $\mathrm{PB}_{-} \mathrm{Fe}_{3} \mathrm{O}_{4}$ [12]. Recently, Ge et al. synthesized $\mathrm{Fe}_{3} \mathrm{O}_{4} @ \mathrm{~PB} \mathrm{NPs}$ by improving shell growing procedure by mixing aqueous dispersion of $\mathrm{Fe}_{3} \mathrm{O}_{4}$ with aqueous solution of $\mathrm{K}_{4} \mathrm{Fe}(\mathrm{CN})_{6}$ in acidic condition under mechanical stirring at room temperature. Subsequently, the aqueous solution of $\mathrm{FeCl}_{3}(\mathrm{pH} 3)$ was added into above mixed to form $\mathrm{Fe}_{3} \mathrm{O}_{4} @ P B$ NPs [13]. Li et al. were also synthesized $\mathrm{Fe}_{3} \mathrm{O}_{4} \mathrm{NPs}_{\text {containing PB }}$ NPs in which $\mathrm{Fe}_{3} \mathrm{O}_{4}$ nanoparticles were prepared by co-precipitating of $\mathrm{Fe}^{2+}$ and $\mathrm{Fe}^{3+}$ ions then the obtained $\mathrm{Fe}_{3} \mathrm{O}_{4}$ particles were re-dispersed by sonication in $\mathrm{K}_{3} \mathrm{Fe}(\mathrm{CN})_{6}$ solution ( $\mathrm{pH}$ 2) followed by addition of $\mathrm{H}_{2} \mathrm{O}_{2}$ as reducing agent and the mixture was stirred for $3 \mathrm{~h}$ to form $\mathrm{Fe}_{3} \mathrm{O}_{4} / \mathrm{PB}$ complex [2]. Zhang et al. presented a simple approach to synthesize $\gamma-\mathrm{Fe}_{2} \mathrm{O}_{3}$ modified PB at different levels. The $\gamma-\mathrm{Fe}_{2} \mathrm{O}_{3}$ NPs were first prepared then the obtained particles were diluted in deionized water ( $\left.\mathrm{pH} 2\right)$ and used as a seeds to prepare $\gamma-\mathrm{Fe}_{2} \mathrm{O}_{3}-\mathrm{PB}$ NPs. An aqueous solution of $\mathrm{K}_{4} \mathrm{Fe}(\mathrm{CN})_{6}$ with different volumes was added dropwise to the $\gamma-\mathrm{Fe}_{2} \mathrm{O}_{3}$ solution under stirring for $1 \mathrm{~h}$ [14].

In the past decades, the synthesis of magnetic-PB NPs has been developed not only for its fundamental scientific interest but also for many technological applications. They has been used in bio-sensing application such as glucose biosensor [2], targeted photothermal therapy of cancer under magnetic resonance imaging (MRI) [13], $\mathrm{H}_{2} \mathrm{O}_{2}$ sensor [12,15] and the removal of cesium from contaminated environment [8]. Recently, the strategies focus on developing these materials in the sensors fabrication because $\mathrm{PB}$, a prototype of mixed valence transition metal hexacyanoferrate is an ancient dye with low cost, good catalytic activities and simple preparation. Moreover, the good characteristic of the reduced form of PB, Prussian White, to catalyze the reduction of $\mathrm{H}_{2} \mathrm{O}_{2}$ at low applied potential can minimize the effects of the most common electrochemical interfering species, which leads interest of research to develop sensors and biosensors based on PB nanocomposite materials. The magnetic nanoparticles have also exhibited substantial application in biomedicine as an enhancement agent especially for the magnetic resonance imaging. The most prominent and the decent characteristics of these nanoparticles are the ability to form stable colloidal suspensions in water without any organic or inorganic coating to prevent their aggregation and, at the same time, they are able to bind specific organic molecules leading to composite materials, which can be exploited for biotechnological applications. Furthermore, nanocomposite magnetic PB materials showed remarkable electrocatalytic properties and were used for the development of sensor and biosensor for hydrogen peroxide and glucose detection with high sensitivity, low detection limit, good reproducibility and stability.

Regardless the interesting properties of magnetic nanoparticles, the applications of pure magnetic nanoparticles are limited due to agglomeration of the fine particles for their large ratio of surface area to volume. The pure magnetic particles are also easily oxidized in air, therefore, losing the magnetic properties [9,12]. The modification of $\mathrm{Fe}_{3} \mathrm{O}_{4}$ particles with polymers, metals and semiconductor materials has been widely involved to overcome these problems.

The composite nanomaterials formed from magnetic $\mathrm{Fe}_{3} \mathrm{O}_{4}$ nanoparticles and $\mathrm{PB}$ would be promising to overcome such problems and be interesting to fabricate glucose biosensors for clinical applications in the human body due to the reliable biosafety [13].

In this work we synthesized magnetite PB nano-composites in one pot hydrothermal procedure. Subsequently, we introduced the magnetite PB nano-composites to fabricate electrochemical glucose 
biosensor via immobilization of GOD-BSA by cross-linking with glutaraldehyde vapor on $\mathrm{Fe}_{3} \mathrm{O}_{4}-\mathrm{PB}$ modified glassy carbon electrode (GCE) surface denoted as (GOD-BSA/Fe $\mathrm{O}_{4}-\mathrm{PB} / \mathrm{GCE}$ ). The combination of $\mathrm{Fe}_{3} \mathrm{O}_{4}-\mathrm{PB}$ nanocomposite and enzyme significantly enhanced the performance such as stability and sensitivity in enzyme biosensor.

\section{Experimental}

\subsection{Chemicals and Reagents}

Glucose oxidase (GOD, EC 1.1.3.4 purified from Aspergillus Niger) was purchased from Sigma (Shanghai, China). Bovine serum albumin (BSA) was bought from Sangon Chemical Company (Shanghai, China). Glutaraldehyde (GA), potassium ferricyanide and potassium chloride were obtained from Shanghai Lingfeng Chemical Company (Shanghai, China). D-(+)-glucose, Iron (III) chloride hexahydrate, hydrogen peroxide and ethylene glycol were obtained from Sinopharm Chemical Company (Shanghai, China) and polyethylene glycol 4000 was obtained from Shantou Xilong Chemical Co., Ltd (Shantou, China).

\subsection{Instruments}

The magnetite PB particles were examined by transmission electron microscope (Gatan, Inc., Pleasanton, CA, USA) and scanning electron microscopy (SEM) and energy dispersive X-ray spectroscopy (EDAX) images were taken with scanning electron microscope (S-3000 N, Hitachi High-Technologies Corporation, Tokyo, Japan). Fourier-transform infrared (Nicolet 5700 FTIR spectrometer, Thermo elctron corporation, Madison, WI, USA ) and UV-Vis absorbance spectroscopy using UV-2450 spectrophotometer (Shimadzu Corporation, Kyoto, Japan) were performed to characterize the magnetite PB particles. Cyclic voltammetry and chronoamperometry were carried out on electrochemical workstation (CHI821C, Shanghai Chenhua Co., Ltd., Shanghai, China). The modified glassy carbon electrode (3.0 $\mathrm{mm}$ in diameter) was used as the working electrode, a saturated calomel electrode (SCE) as the reference electrode and a platinum wire as the auxiliary electrode.

\subsection{One-Pot Synthesis of Magnetite PB Nanoparticles}

All of the reagents in this experiment are analytical grade and used without further purification. Magnetite PB nanoparticles were synthesized via one-pot hydrothermal reduction of $\mathrm{FeCl}_{3} \cdot 6 \mathrm{H}_{2} \mathrm{O}$ and $\mathrm{K}_{3} \mathrm{Fe}(\mathrm{CN})_{6}$ by the ethylene glycol (EG) in the presence of polyethylene glycol (PEG) as surfactant. Typically, $\mathrm{FeCl}_{3} \cdot 6 \mathrm{H}_{2} \mathrm{O} 1.3 \mathrm{~g}(0.124 \mathrm{M})$ was dissolved in $40 \mathrm{~mL}$ of EG followed by addition of $1.0 \mathrm{~g}$ PEG under mechanical stirring. $0.67 \mathrm{~g} \mathrm{~K}_{3} \mathrm{Fe}(\mathrm{CN})_{6}(0.049 \mathrm{M})$ was added to the above solution and continued stirred vigorously for $1 \mathrm{~h}$ and then transferred into Teflon-lined stainless-steel autoclave. The autoclave was then heated and maintained at $190{ }^{\circ} \mathrm{C}$ for $12 \mathrm{~h}$. Afterward the autoclave was allowed to cool overnight at room temperature. The precipitation was collected by magnetic separation, washed several times with distilled water and dried for $6 \mathrm{~h}$ in oven at $60{ }^{\circ} \mathrm{C}$. The preparation and purification process has been illustrated in Scheme 1.

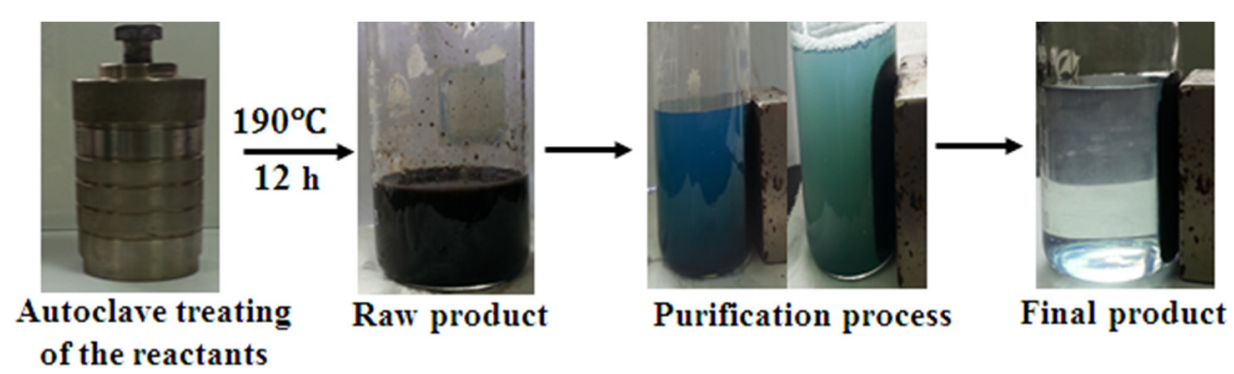

Scheme 1. Synthesis and purification process of the magnetite Prussian blue (PB) nano-composites. 


\subsection{Preparation of Glucose Oxidase Biosensor on Magnetite PB Modified Glassy Carbon Electrode}

The GCE was polished before each experiment with 1.0, 0.3, and $0.05 \mu \mathrm{m} \alpha$-alumina powder, respectively, rinsed thoroughly with double distilled water. $1 \mathrm{mg} / \mathrm{mL}$ of synthesized magnetite PB nanocomposite was dispersed in double distilled water and then $6 \mu \mathrm{L}$ of magnetite PB solution was dropped onto the cleaned GCE surface allowed to dry at room temperature followed by heating for $1 \mathrm{~h}$ at $100{ }^{\circ} \mathrm{C}$ denoted as $\left(\mathrm{Fe}_{3} \mathrm{O}_{4}-\mathrm{PB} / \mathrm{GCE}\right)$. GOD $(5 \mathrm{mg} / \mathrm{mL})$ was prepared in PBS $(\mathrm{pH} 6.5) ; \mathrm{BSA}(5 \mathrm{mg} / \mathrm{mL})$ was also prepared in PBS (pH 6.5). Enzyme mixture was prepared by mixing (1:1 V/V) GOD and BSA then $5 \mu \mathrm{L}$ of enzyme mixture was dropped onto the obtained $\mathrm{Fe}_{3} \mathrm{O}_{4}-\mathrm{PB} / \mathrm{GCE}$ and allowed to dry at $4{ }^{\circ} \mathrm{C}$ in refrigerator then the electrode was introduced to glutaraldehyde (25\%) vapor for cross-linking of enzyme mixture for $15 \mathrm{~min}$. The final modified electrode is denoted as GOD-BSA/Fe $\mathrm{O}_{4}-\mathrm{PB} / \mathrm{GCE}$. The biosensor preparation steps have been shown in Scheme 2.

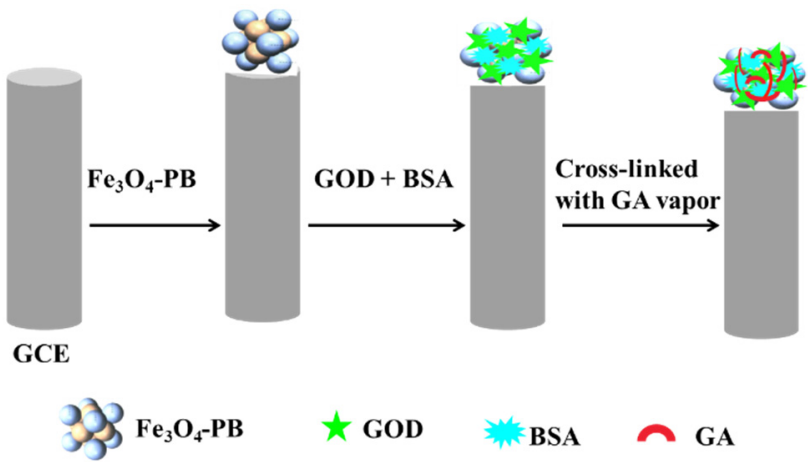

Scheme 2. Steps to fabricate the biosensor.

\section{Results and Discussion}

\subsection{Possible Formation Mechanism of Magnetite PB Nanocomposite}

We prepared magnetite PB nanoparticles by one-pot hydrothermal route using ferric (III) chloride and potassium ferricyanide as precursors, ethylene glycol as solvent and reducing reagent and PEG as protective reagent to keep nanoparticles from agglomeration. During the hydrothermal process, EG can reduce some of $\mathrm{Fe}^{3+}$ ions to $\mathrm{Fe}^{2+}$ ions to form $\mathrm{Fe}(\mathrm{OH})_{3}$ and $\mathrm{Fe}(\mathrm{OH})_{2}$ by hydrolysis firstly. The hydroxides finally become $\mathrm{Fe}_{3} \mathrm{O}_{4}$ nanoparticles by thermal decomposition [16,17]. Concerning to the formation of magnetite $\mathrm{PB}$, there are two possibilities: (1) The above-formed $\mathrm{Fe}^{2+}$ ions in the reaction medium could react with $\mathrm{Fe}(\mathrm{CN})_{6}{ }^{3-}$ to form $\mathrm{PB}$ nanoparticles, which precipitate onto $\mathrm{Fe}_{3} \mathrm{O}_{4}$ nanoparticles surface to form the final nanocomposites via the electrostatic attraction between $\mathrm{Fe}_{3} \mathrm{O}_{4}$ nanoparticles and PB nanoparticles [18]; (2) $\mathrm{Fe}(\mathrm{CN})_{6}{ }^{3-}$ might be reduced to $\mathrm{Fe}(\mathrm{CN})_{6}{ }^{4-}$, which can react with $\mathrm{Fe}^{3+}$ ions adsorbed on the formed $\mathrm{Fe}_{3} \mathrm{O}_{4}$ nanoparticles surface to form the final products. After the hydrothermal reaction, the color of the product was dark blue and the formed particles could be separated by external magnet indicating the magnetic PB nanocomposites have been successfully prepared (Scheme 1).

\subsection{Characterization}

The morphologies of the magnetite PB nanocomposites were characterized by TEM. Figure 1 shows the TEM results of the typical synthesized magnetite PB nanocomposites. Numerous spherical and cubic nanoparticles combined compactly together were observed. The spherical and cubic nanoparticles belong to $\mathrm{Fe}_{3} \mathrm{O}_{4}$ and $\mathrm{PB}$, respectively. Meanwhile, $\mathrm{Fe}_{3} \mathrm{O}_{4}-\mathrm{PB}$ nanocomposites thin film and GOD-BSA $/ \mathrm{Fe}_{3} \mathrm{O}_{4}-\mathrm{PB}$ thin film modified electrodes were characterized by SEM. Figure 2 shows their SEM images. As seen in Figure 2A, the morphologies of $\mathrm{Fe}_{3} \mathrm{O}_{4}-\mathrm{PB}$ nanocomposites were consistent with the results from their TEM measurements. After the $\mathrm{Fe}_{3} \mathrm{O}_{4}-\mathrm{PB}$ modified electrode was 
coated with GOD and BSA mixture via cross-linking by glutaraldehyde, it is apparent to observe an enzyme membrane covered on $\mathrm{Fe}_{3} \mathrm{O}_{4}$-PB film (Figure 2B). To further verify the formation of magnetite PB nano-composites, EDAX was performed upon magnetite PB nanocomposites modified platinum sheet. As seen in Figure S1, (in the supplementary materials), elements content of the nanocomposites showed the existing of $\mathrm{C}, \mathrm{N}, \mathrm{O}$ and $\mathrm{Fe}$, which are typical elements of $\mathrm{Fe}_{3} \mathrm{O}_{4}$ and $\mathrm{PB}$.

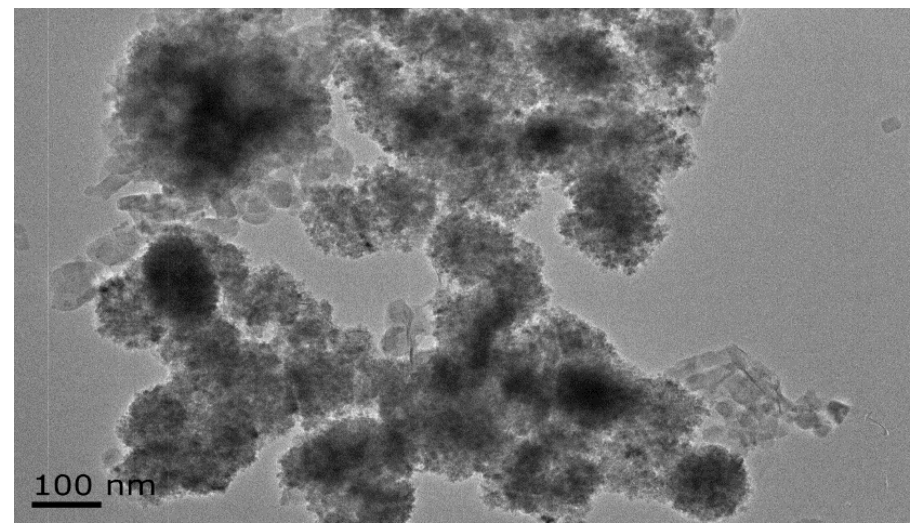

Figure 1. TEM image of the magnetite PB nano-composites.

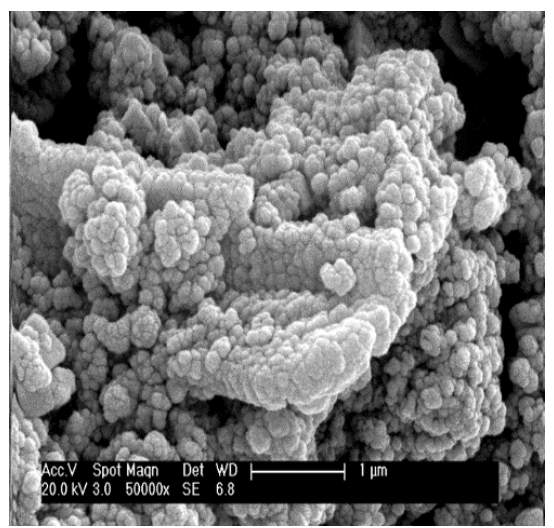

(A)

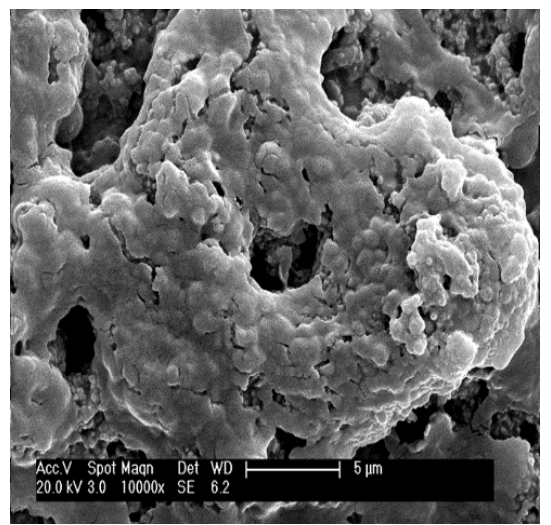

(B)

Figure 2. SEM images of (A) $\mathrm{Fe}_{3} \mathrm{O}_{4}-\mathrm{PB}$ film and (B) Glucose oxidase (GOD)-bovine serum albumin (BSA) $/ \mathrm{Fe}_{3} \mathrm{O}_{4}-\mathrm{PB}$ film.

As shown in Figure 3A, FTIR was also used to characterize $\mathrm{Fe}_{3} \mathrm{O}_{4}$ (Figure 3A, curve a) and magnetite $\mathrm{PB}$ nanoparticles (Figure 3A, curve b). In Figure 3A, curve a, the absorption band at $573 \mathrm{~cm}^{-1}$ is assigned to the absorption peak of $\mathrm{Fe}-\mathrm{O}$ bonds [19]. The absorption peaks at around 3315 and $1600 \mathrm{~cm}^{-1}$ are related to $\mathrm{O}-\mathrm{H}$ and $\mathrm{H}-\mathrm{O}-\mathrm{H}$, respectively, which are attributed to the existence of interstitial water in the particles [12]. For the magnetite PB particles (Figure 3A, curve b), the absorption band at $2085 \mathrm{~cm}^{-1}$ are attributed to the $C N$ group, the absorption band at $496 \mathrm{~cm}^{-1}$ belongs to the $\mathrm{Fe}-\mathrm{CN}-\mathrm{Fe}[8,12,20]$, and the absorption peak at $596 \mathrm{~cm}^{-1}$ refers to the $\mathrm{Fe}-\mathrm{O}$ bond. Existence of peaks at 2085, 496, and $596 \mathrm{~cm}^{-1}$ confirmed the formation of magnetite PB nanoparticles through one pot hydrothermal synthesis. The $\mathrm{Fe}-\mathrm{O}$ band shifted from $\mathrm{Fe}_{3} \mathrm{O}_{4}$ to magnetite $\mathrm{PB}$ to higher wavenumbers of $596 \mathrm{~cm}^{-1}$. This phenomenon is indicating the formation of the nanocomposite. One of the basic influences of the finite size of NPs is the breaking of a large number of bonds for surface atoms, resulting in the rearrangement of dissociative electrons on the particle surface. Hence, when particles are reduced to nanoscale dimensions, the absorption bands of FTIR spectra shift to higher wavenumbers [14]. 

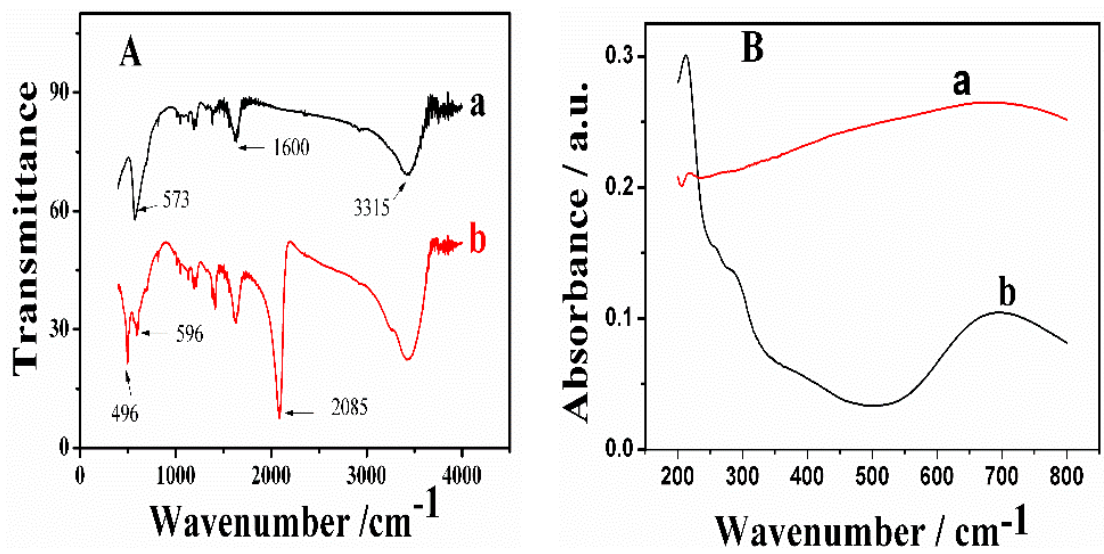

Figure 3. (A) FTIR spectra of pure $\mathrm{Fe}_{3} \mathrm{O}_{4}$ nanoparticles (curve a) and magnetite PB nano-composites (curve b); (B) UV-vis absorption spectra of $\mathrm{Fe}_{3} \mathrm{O}_{4}$ nanoparticles (curve a) and magnetite $\mathrm{PB}$ nano-composites (curve b).

$\mathrm{UV}$-vis spectroscopy was further used to investigate the formation of the magnetite $\mathrm{PB}$ composite as shown in Figure 3B. For pure $\mathrm{Fe}_{3} \mathrm{O}_{4}$ nanoparticles (Figure 3B, curve a), no clear absorbance peaks could be observed due to its wide spectrum absorbance property. However, for the magnetite $\mathrm{PB}$ composite (Figure 3B, curve b), the mixed valence charge transfer band of the $\mathrm{PB} \mathrm{Fe} \mathrm{e}^{\mathrm{II}}-\mathrm{C}-\mathrm{N}-\mathrm{Fe}^{\mathrm{III}}$ at around $740 \mathrm{~nm}$ was observed. Both results obtained from FTIR and UV-vis showed good agreement to the results reported in the literature [21,22].

\subsection{Electrochemical Behaviors of $\mathrm{Fe}_{3} \mathrm{O}_{4}-\mathrm{PB}$ and $\mathrm{GOD}-\mathrm{BSA} / \mathrm{Fe}_{3} \mathrm{O}_{4}-\mathrm{PB} / \mathrm{GCE}$}

To investigate the electrochemical behaviors of the synthesized magnetite PB nanocomposites and its corresponding glucose oxidase biosensor, cyclic voltammetry and chronoamperometry were performed. As shown in Figure 4, two pairs of anodic and cathodic peaks were observed from cyclic voltammogram (CV) of $\mathrm{Fe}_{3} \mathrm{O}_{4}$-PB/GCE in $0.01 \mathrm{M}$ PBS ( $\mathrm{pH}$ 6.0) containing $0.1 \mathrm{M} \mathrm{KCl}$ at the scan rate of $100 \mathrm{~m} \cdot \mathrm{Vs}^{-1}$. The two pair of peaks were attributed to the oxidation of PB to Prussian green (PG) and the reduction of PB to Prussian white (PW), respectively. Clearly, from the shape of $\mathrm{CV}$, the synthesized nano-composites contain PB [23].This result is with good agreement to the above-mentioned other characterization.

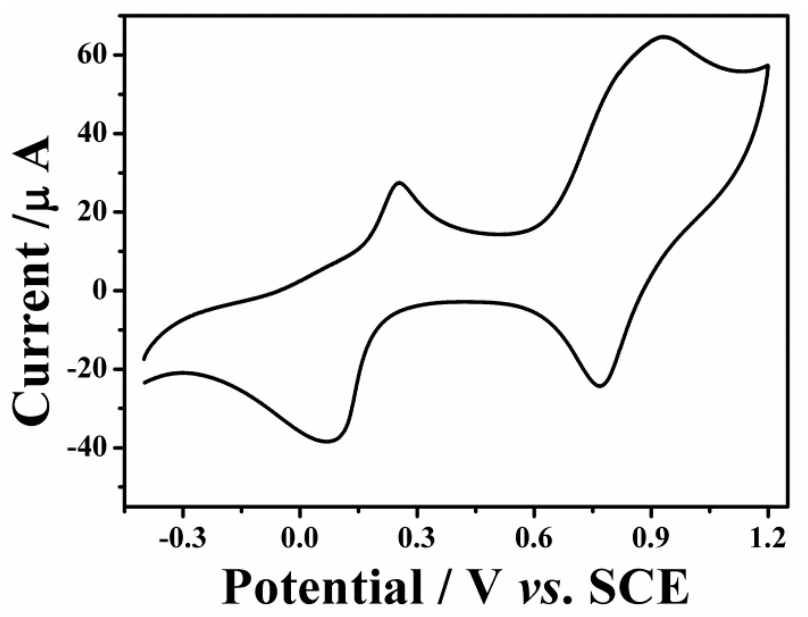

Figure 4. Cyclic voltammogram (CV) of the magnetite PB nano-composites modified glassy carbon electrode (GCE) in $0.1 \mathrm{M}$ PBS ( $\mathrm{pH}$ 6.0) with the scan rate of $100 \mathrm{mV} \cdot \mathrm{s}^{-1}$. 
The conventional PB modified electrodes suffer from the instability of the film in neutral and alkaline conditions due to the presence of hydroxide ions, which could break Fe-(CN)-Fe bonds. Therefore, we investigated the $\mathrm{pH}$ effect to magnetite $\mathrm{PB}$ modified electrode in PBS with the $\mathrm{pH}$ values ranging from 5 to 9. Figure S2 (supplementary materials) showed multi-CVs of $\mathrm{Fe}_{3} \mathrm{O}_{4}-\mathrm{PB} / \mathrm{GCE}$ in different PBS at scan rate of $100 \mathrm{mV} \cdot \mathrm{s}^{-1}$. The modified electrodes exhibited good stabilities in $\mathrm{pH} 5$ to 7. However, the current peaks showed a little decrease in $\mathrm{pH} 8$ and 9 upon 20 potential scanning cycles on each $\mathrm{pH}$ value. The current peak is almost unchanged which reveals that no proton is involved in the electrochemical reaction of PB. As well-known, the unmodified PB film is highly unstable in neutral and alkaline solution, and it has significant loss of redox activity. The good stability of the $\mathrm{Fe}_{3} \mathrm{O}_{4}$-PB/GCE may be due to the presence of the magnetic ions on the magnetite PB nano-composites which block the attack of hydroxide ions towards PB. In conclusion, electrostatic interaction between $\mathrm{Fe}_{3} \mathrm{O}_{4}$ and $\mathrm{PB}$ may offer stabilization mechanism to prevent its dissolution.

The electro-catalysis of $\mathrm{Fe}_{3} \mathrm{O}_{4}-\mathrm{PB} / \mathrm{GCE}$ to $\mathrm{H}_{2} \mathrm{O}_{2}$ was investigated by cyclic voltammetry. Figure 5 shows the $\mathrm{CVs}$ of the $\mathrm{Fe}_{3} \mathrm{O}_{4}$-PB/GCE upon different concentrations of $\mathrm{H}_{2} \mathrm{O}_{2}$ in $0.01 \mathrm{M} \mathrm{PBS}$ (pH 6.0) containing $0.1 \mathrm{M} \mathrm{KCl}$. The potential scan range was between -0.3 and $0.6 \mathrm{~V} v$ s. SCE and the scan rate is $100 \mathrm{mV} \cdot \mathrm{s}^{-1}$. The reduction current peaks increased significantly in magnitude upon increasing concentrations of $\mathrm{H}_{2} \mathrm{O}_{2}$ and the oxidation peaks decreased correspondingly, which demonstrated the electrocatalytic reduction of $\mathrm{H}_{2} \mathrm{O}_{2}$.

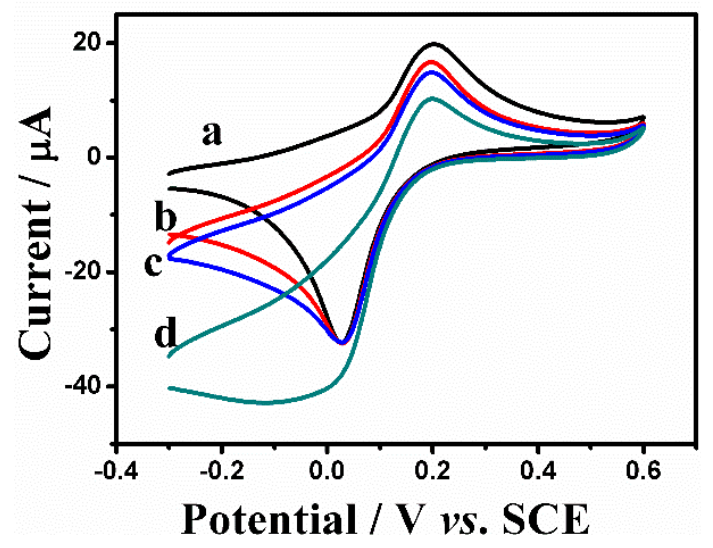

Figure 5. CVs of magnetite PB nano-composites modified GCE in the absence (a) and presence of $1 \mathrm{mM}$ (b), $2 \mathrm{mM}(\mathbf{c})$, and $4 \mathrm{mM} \mathrm{H} \mathrm{H}_{2}$ (d) in $0.1 \mathrm{M}$ PBS (pH 6.0) with the scan rate of $100 \mathrm{mV} \cdot \mathrm{s}^{-1}$.

As shown in Figure S3 (in the supplementary materials), the amperometric determination of $\mathrm{H}_{2} \mathrm{O}_{2}$ was performed by successive addition of $\mathrm{H}_{2} \mathrm{O}_{2}$ into $0.01 \mathrm{M}$ PBS ( $\mathrm{pH}$ 6.0) containing $0.1 \mathrm{M} \mathrm{KCl}$ under stirring at $-0.1 \mathrm{~V}$. The amperogram of the $\mathrm{Fe}_{3} \mathrm{O}_{4}-\mathrm{PB} / \mathrm{GCE}$ displayed fast response and stable signal with injection of $\mathrm{H}_{2} \mathrm{O}_{2}$. The response time is only $4-5 \mathrm{~s}$.

Compared with $\mathrm{Fe}_{3} \mathrm{O}_{4}$-PB/GCE, an obvious decrease of peak currents was observed in the GOD-BSA/ $\mathrm{Fe}_{3} \mathrm{O}_{4}-\mathrm{PB} / \mathrm{GCE}$ as shown in Figure S4 (in the supplementary materials). This was attributed to the block effect of enzyme membrane to the mass transportation, which is consistent with the SEM measurement (Figure 2).

Figure 6 showed the typical CVs of GOD-BSA/ $\mathrm{Fe}_{3} \mathrm{O}_{4}-\mathrm{PB} / \mathrm{GCE}$ for glucose detection. In the presence of $1 \mathrm{mM}$ glucose, the cathodic peak current increased and the anodic peak current decreased indicating catalytic reduction reaction. The description for this reaction process is that glucose diffuses from the electrolyte solution to the enzyme film on the electrode surface then GOD catalyzes the oxidation of glucose resulting in the generation of $\mathrm{H}_{2} \mathrm{O}_{2}$ and gluconic acid in consumption of oxygen. Subsequently, the generated $\mathrm{H}_{2} \mathrm{O}_{2}$ is then catalytically reduced by Prussian white (the reduced form of PB) [24]. 


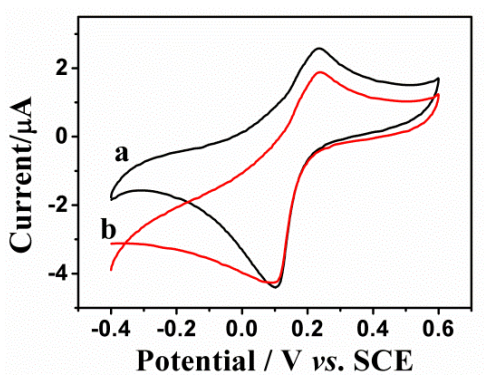

Figure 6. CVs obtained at the GOD-BSA $/ \mathrm{Fe}_{3} \mathrm{O}_{4}$-PB/GCE in $0.01 \mathrm{M}$ PBS (pH 6.0) containing $0.1 \mathrm{M} \mathrm{KCl}$ in the absence (a) and presence (b) of $1 \mathrm{mM}$ glucose with the scan rate of $50 \mathrm{mV} \mathrm{s}^{-1}$.

\subsection{Detection of Glucose}

For the fabrication of GOD-BSA $/ \mathrm{Fe}_{3} \mathrm{O}_{4}-\mathrm{PB} / \mathrm{GCE}$, the effect of cross-linking time in glutaraldehyde vapor was investigated from $5 \mathrm{~min}$ to $30 \mathrm{~min}$. The optimal time is $15 \mathrm{~min}$. A short time in the vapor leads the instability of the enzyme membrane due to the insufficient cross-linking. A long time in glutaraldehyde causes the decreasing of the bioactivity of GOD. For the detection of glucose, the applied potential of $-0.15 \mathrm{~V}$ was chosen to perform the current-time response experiment due to the acceptable sensitivity and avoiding the interference of electroactive species shown in Figure S5. The sensitivity and the bioactivity of the biosensor greatly depend on the solution $\mathrm{pH}$ values. The current-time response of GOD-BSA/ $\mathrm{Fe}_{3} \mathrm{O}_{4}-\mathrm{PB} / \mathrm{GCE}$ in PBS with different $\mathrm{pH}$ values (from 4 to 9) with the injection of $0.4 \mathrm{mM}$ glucose was investigated. The current peak response reached its maximum at $\mathrm{pH}$ 6.0, which is consistent with the optimal enzyme activity and the performance of $\mathrm{Fe}_{3} \mathrm{O}_{4}-\mathrm{PB}$ in acidic condition. Hence, the $\mathrm{pH} 6.0$ is selected as the optimal value for this biosensor.

Under the optimal conditions, the current-time response of GOD-BSA $/ \mathrm{Fe}_{3} \mathrm{O}_{4}-\mathrm{PB} / \mathrm{GCE}$ upon successive addition of glucose $(0.5 \mu \mathrm{M}$ and $1500 \mu \mathrm{M})$ in $0.01 \mathrm{M}$ PBS (pH6.0) containing $0.1 \mathrm{M} \mathrm{KCl}$ under stirring was shown in Figure 7. The electrocatalysis current reached $95 \%$ of its steady current within short time about 3-4 s after the injection of glucose indicating the biosensor has fast response. Meanwhile, the biosensor exhibited wide linear range to glucose concentration from 5 to $1200 \mu \mathrm{M}$ with a sensitivity of $32 \mu \mathrm{A} \cdot \mathrm{mM}^{-1} \cdot \mathrm{cm}^{-2}$ and the limit of detection of $0.5 \mu \mathrm{M}$. The inset in Figure 7 displayed the corresponding calibration curve for glucose. The wide linear range of this biosensor may be due to the big loading of enzymes using the cross-linking method. The usage of BSA might not only provide sufficient amino groups for cross-linking via glutaraldehyde to stabilize GOD but also provide biocompatible surroundings to maintain the bioactivity of GOD. Table 1 shows the performance comparison of this work with other recently reported biosensors in the term of detection limit, linear range, sensitivity and response time.

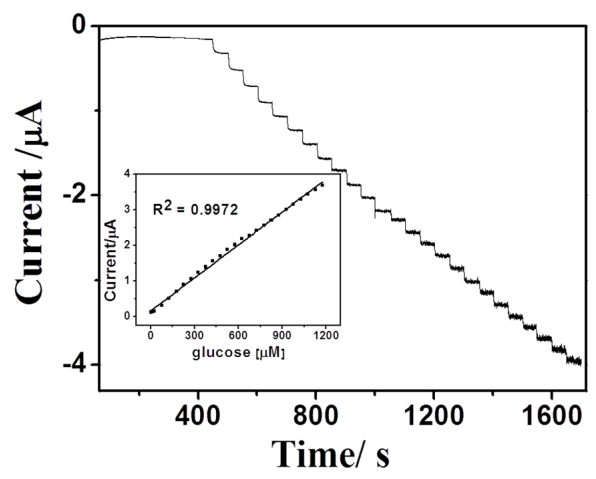

Figure 7. Current-time response of the biosensor upon successive addition of different concentrations of glucose from $5 \mu \mathrm{M}$ to $1500 \mu \mathrm{M}$ in $0.01 \mathrm{M}$ PBS ( $\mathrm{pH}$ 6.0) containing $0.1 \mathrm{M} \mathrm{KCl}$ under stirring. The applied potential was $-0.15 \mathrm{~V}$. Inset: the catalytic response $v$ s. glucose concentration. 
Table 1. Comparison of electrocatalytic activities of this work with the previous reported.

\begin{tabular}{cccccc}
\hline Working Electrode & LOD $(\mu \mathrm{M})$ & Linear Range & Sensitivity & $\begin{array}{c}\text { Response } \\
\text { Time (s) }\end{array}$ & Reference \\
\hline PB/GOD/TEOS-PVA/NAFION & 20 & $5-1000 \mu \mathrm{M}$ & $2.06 \mu \mathrm{A} \cdot \mathrm{mM}^{-1} \cdot \mathrm{cm}^{-2}$ & No data & {$[25]$} \\
Anodisc ${ }^{\mathrm{TM}} / \mathrm{Pt} / \mathrm{PPy} / \mathrm{GOx}$ & 50 & $0.2-13 \mathrm{mM}$ & $72.1 \mathrm{~mA} \cdot \mathrm{M}^{-1} \cdot \mathrm{cm}^{-2}$ & 13 & {$[26]$} \\
nanotube arrays $_{\mathrm{Fe}_{3} \mathrm{O}_{4} / \mathrm{PB} / \mathrm{GOD}}$ & 0.1 & $0.5-80 \mu \mathrm{M}$ & $\mathrm{No} \mathrm{data}$ & 10 & {$[2]$} \\
$\mathrm{GOx} / \mathrm{Chi}-\mathrm{IL} / \mathrm{PB} / \mathrm{Pt}$ & 5 & $0.01-4.2 \mathrm{mM}$ & $37.8 \mu \mathrm{A} \cdot \mathrm{mM}^{-1} \cdot \mathrm{cm}^{-2}$ & 3 & {$[27]$} \\
$\mathrm{GOx}-\mathrm{PDA} / \mathrm{PB} / \mathrm{GCE}$ & 46.2 & $0.2-3.4 \mathrm{mM}$ & $1.59 \mathrm{nA} \cdot \mu \mathrm{M}^{-1}$ & 15 & {$[28]$} \\
$\mathrm{PBNPs}-\mathrm{PANI} / \mathrm{MWNTs} / \mathrm{GCE}$ & 0.6 & $6.7-1900 \mu \mathrm{M}$ & $6.28 \mu \mathrm{Am}^{-1}$ & 5 & {$[29]$} \\
$\mathrm{PVA}-\mathrm{Au}-\mathrm{pphTEOS}-\mathrm{GOD}$ & 700 & $1-8 \mathrm{mM}$ & $49 \mu \mathrm{A} \cdot \mathrm{mM}^{-1} \cdot \mathrm{cm}^{-2}$ & 6 & {$[30]$} \\
$\mathrm{Alg} / \mathrm{LDHs} / \mathrm{GOD} / \mathrm{Pt}$ & 4 & $0.016-2 \mathrm{mM}$ & $68.9 \mathrm{~mA} \cdot \mathrm{M}^{-1} \cdot \mathrm{cm}^{-2}$ & 10 & {$[31]$} \\
GOD-BSA/GA/Fe $/ \mathrm{O}_{4}-\mathrm{PB} / \mathrm{GCE}$ & 0.5 & $5-1200 \mu \mathrm{M}$ & $32 \mu \mathrm{A} \cdot \mathrm{mM}^{-1} \cdot \mathrm{cm}^{-2}$ & 4 & This work \\
\hline
\end{tabular}

\subsection{Storage Stability of the Biosensor}

In order to investigate the storage stability of the biosensor, cyclic voltammetry was used to detect constant concentration of glucose daily for two weeks. The biosensor showed acceptable stability with decreasing in current peaks about $5 \%-8 \%$ from its initial value. The long term stability of the biosensor attributed to the stability of the $\mathrm{Fe}_{3} \mathrm{O}_{4}-\mathrm{PB}$ nanocomposite film and the cross-linking enzyme membrane allowed large loading of the enzyme.

\section{Conclusions}

Electroactive $\mathrm{Fe}_{3} \mathrm{O}_{4}-\mathrm{PB}$ nano-composites have been synthesized in one-pot hydrothermal approach for the first time. $\mathrm{Fe}_{3} \mathrm{O}_{4}$-PB nano-composites modified GCE exhibited good performance in electro-catalysis of hydrogen peroxide, especially its stability. Furthermore, a highly sensitive glucose biosensor was developed via cross-linking of GOD-BSA onto $\mathrm{Fe}_{3} \mathrm{O}_{4}-\mathrm{PB}$ nano-composites modified GCE. The cross-linking between BSA and GOD guaranteed for more loading and good stability of GOD. The association of magnetite PB could improve the stability of PB film. Obviously, The $\mathrm{Fe}_{3} \mathrm{O}_{4}-\mathrm{PB}$ nano-composites film could be used as a promising platform for the development of biosensors related to hydrogen peroxide.

Supplementary Materials: The following are available online at http:/ /www.mdpi.com/1424-8220/16/2/243, Figure S1: EDAX showing the elements content of the composite $\mathrm{Fe}_{3} \mathrm{O}_{4}$-Prussian blue. Figure S2: Multi-CVs of the $\mathrm{Fe}_{3} \mathrm{O}_{4}$-PB/GCE in $0.01 \mathrm{M}$ Phosphate buffer solution (PBS) containing $0.1 \mathrm{M} \mathrm{KCl}$ at deferent $\mathrm{pH}$ values (A) 5.0, (B) 6.0, (C) 7.0, (D) 8.0, (E) 9.0. Figure S3: Current-time response of the $\mathrm{Fe}_{3} \mathrm{O}_{4}$-PB/GCE to the successive addition of $\mathrm{H}_{2} \mathrm{O}_{2}$ in $0.01 \mathrm{M}$ PBS ( $\mathrm{pH} 6.0$ ) $+0.1 \mathrm{M} \mathrm{KCl}$ under stirring at $-0.1 \mathrm{~V}$. Insert: Plot of catalytic current $v s . \mathrm{H}_{2} \mathrm{O}_{2}$ concentration. Figure S4: Typical CVs obtained at $\mathrm{Fe}_{3} \mathrm{O}_{4}-\mathrm{PB} / \mathrm{GCE}(\mathbf{A})$ and GOD-BSA/ $\mathrm{Fe}_{3} \mathrm{O}_{4}-\mathrm{PB} / \mathrm{GCE}(\mathbf{B})$ in $0.01 \mathrm{M}$ PBS $\left(\mathrm{pH} \mathrm{6.0)}+0.1 \mathrm{M} \mathrm{KCl}\right.$. Scan rate: $50 \mathrm{mV} \cdot \mathrm{s}^{-1}$. Figure S5: Typical Chronoaperometry (I-t) response of $0.025 \mu \mathrm{M}$ glucose and (A) $0.1 \mu \mathrm{M}$ AA and $0.1 \mu \mathrm{M} \mathrm{UA}$ (B) $0.2 \mu \mathrm{M} \mathrm{AA}$ and $0.2 \mu \mathrm{M} \mathrm{UA}$ at GOD-BSA/Fe $\mathrm{O}_{4}-\mathrm{PB} / \mathrm{GCE}$. Applied Potential: $-0.15 \mathrm{~V}$.

Acknowledgments: This work was supported by the National Natural Science Foundation of China (Grant Nos. 21575022 and 21535003), the National High Technology Research and Development Program ("863" Program) of China (Grant No. 2015AA020502), the Open Research Fund of Key Laboratory of Energy Thermal Conversion and Control of Ministry of Education, Southeast University, and the Fundamental Research Funds for the Central Universities.

Author Contributions: Shou-Nian Ding conceived and designed the experiments; Ezzaldeen Younes Jomma performed the experiments; Both of them analyzed the data and completed the writing of the paper.

Conflicts of interest: The authors declare no conflict of interest.

\section{References}

1. Wang, C.; Chen, S.; Xiang, Y.; Li, W.; Zhong, X.; Che, X.; Li, J. Glucose biosensor based on the highly efficient immobilization of glucose oxidase on Prussian blue-gold nanocomposite films. J. Mol. Catal. B Enzym. 2011, 69, 1-7. [CrossRef] 
2. Li, J.; Wei, X.; Yuan, Y. Synthesis of magnetic nanoparticles composed by Prussian blue and glucose oxidase for preparing highly sensitive and selective glucose biosensor. Sens. Actuators B Chem. 2009, 139, 400-406. [CrossRef]

3. Fu, G.; Liu, W.; Feng, S.; Yue, X. Prussian blue nanoparticles operate as a new generation of photothermal ablation agents for cancer therapy. Chem. Commun. 2012, 48, 11567-11569. [CrossRef] [PubMed]

4. Pandey, P.C.; Pandey, A.K. Tetrahydrofuran hydroperoxide mediated synthesis of Prussian blue nanoparticles: A study of their electrocatalytic activity and intrinsic peroxidase-like behavior. Electrochim. Acta 2014, 125, 465-472. [CrossRef]

5. Wu, J.; Yin, F. Sensitive enzymatic glucose biosensor fabricated by electrospinning composite nanofibers and electrodepositing Prussian blue film. J. Electroanal. Chem. 2013, 694, 1-5. [CrossRef]

6. Du, J.; Wang, Y.; Zhou, X.; Xue, Z.; Liu, X.; Sun, K.; Lu, X. Improved sensing in physiological buffers by controlling the nanostructure of Prussian blue film. J. Phys. Chem. C 2010, 114, 14786-14793. [CrossRef]

7. Salazar, P.; Martín, M.; O’Neill, R.D.; Roche, R.; González-Mora, J.L. Improvement and characterization of surfactant-modified Prussian blue screen-printed carbon electrodes for selective $\mathrm{H}_{2} \mathrm{O}_{2}$ detection at low applied potentials. J. Electroanal. Chem. 2012, 674, 48-56. [CrossRef]

8. Thammawong, C.; Opaprakasit, P.; Tangboriboonrat, P.; Sreearunothai, P. Prussian blue-coated magnetic nanoparticles for removal of cesium from contaminated environment. J. Nanopart. Res. 2013, 15, 1-10. [CrossRef]

9. Lu, A.H.; Salabas, E.L.; Schuth, F. Magnetic nanoparticles: Synthesis, protection, functionalization, and application. Angew. Chem. 2007, 46, 1222-1244. [CrossRef] [PubMed]

10. Laurent, S.; Forge, D.; Port, M.; Roch, A.; Robic, C.; Vander Elst, L.; Muller, R.N. Magnetic iron oxide nanoparticles: Synthesis, stabilization, vectorization, physicochemical characterizations, and biological applications. Chem. Rev. 2008, 108, 2064-2110. [CrossRef] [PubMed]

11. Wu, W.; Wu, Z.; Yu, T.; Jiang, C.; Kim, W.-S. Recent progress on magnetic iron oxide nanoparticles: Synthesis, surface functional strategies and biomedical applications. Sci. Technol. Adv. Mater. 2015, 16. [CrossRef]

12. Zhao, G.; Feng, J.; Zhang, Q.; Li, S.; Chen, H.-Y. Synthesis and characterization of Prussian blue modified magnetite nanoparticles and its application to the electrocatalytic reduction of $\mathrm{H}_{2} \mathrm{O}_{2}$. Chem. Mater. 2005, 17, 3154-3159. [CrossRef]

13. Fu, G.; Liu, W.; Li, Y.; Jin, Y.; Jiang, L.; Liang, X.; Feng, S.; Dai, Z. Magnetic Prussian blue nanoparticles for targeted photothermal therapy under magnetic resonance imaging guidance. Bioconjugate Chem. 2014, 25, 1655-1663. [CrossRef] [PubMed]

14. Zhang, X.; Gong, S.; Zhang, Y.; Yang, T.; Wang, C.; Gu, N. Prussian blue modified iron oxide magnetic nanoparticles and their high peroxidase-like activity. J. Mater. Chem. 2010, 20, 5110-5116. [CrossRef]

15. Massimiliano, M.; Davide, B.; Gabriella, S.; Katerin, P.; Giorgio, Z.; Jiri, T.; Josef, K.; Radek, Z.; Fabio, V. Core-shell hybrid nanomaterial based on Prussian blue and surface active maghemite nanoparticles as stable electrocatalyst. Biosens. Bioelectron. 2014, 52, 159-165.

16. Liu, S.; Xing, R.; Lu, F.; Rana, R.K.; Zhu, J.-J. One-pot template-free fabrication of hollow magnetite nanospheres and their application as potential drug carriers. J. Phys. Chem. C 2009, 113, 21042-21047. [CrossRef]

17. Cheng, W.; Tang, K.; Qi, Y.; Sheng, J.; Liu, Z. One-step synthesis of superparamagnetic monodisperse porous $\mathrm{Fe}_{3} \mathrm{O}_{4}$ hollow and core-shell spheres. J. Mater. Chem. 2010, 20, 1799-1805. [CrossRef]

18. Arun, T.; Prakash, K.; Kuppusamy, R.; Joseyphus, R.J. Magnetic properties of Prussian blue modified $\mathrm{Fe}_{3} \mathrm{O}_{4}$ nanocubes. J. Phys. Chem. Solids 2013, 74, 1761-1768. [CrossRef]

19. Daou, T.J.; Grenèche, J.M.; Pourroy, G.; Buathong, S.; Derory, A.; Ulhaq-Bouillet, C.; Donnio, B.; Guillon, D.; Begin-Colin, S. Coupling agent effect on magnetic properties of functionalized magnetite-based nanoparticles. Chem. Mater. 2008, 20, 5869-5875. [CrossRef]

20. Hu, M.; Furukawa, S.; Ohtani, R.; Sukegawa, H.; Nemoto, Y.; Reboul, J.; Kitagawa, S.; Yamauchi, Y. Synthesis of Prussian blue nanoparticles with a hollow interior by controlled chemical etching. Angew. Chem. 2012, 51, 984-988. [CrossRef] [PubMed]

21. Li, J.; Yuan, Y. Synthesis of magnetic Prussian blue nanoparticles and the fabrication of chemically modified electrode. Acta Chim. Sin. 2006, 64, 261-265. 
22. Darder, M.; González-Alfaro, Y.; Aranda, P.; Ruiz-Hitzky, E. Silicate-based multifunctional nanostructured materials with magnetite and Prussian blue: Application to cesium uptake. RSC Adv. 2014, 4, 35415-35421. [CrossRef]

23. Jiang, C.; Lin, X. Electrochemical synthesis of $\mathrm{Fe}_{3} \mathrm{O}_{4}-\mathrm{PB}$ nanoparticles with core-shell structure and its electrocatalytic reduction toward $\mathrm{H}_{2} \mathrm{O}_{2}$. J. Solid State Electrochem. 2008, 13, 1273-1278.

24. Xue, M.-H.; Xu, Q.; Zhou, M.; Zhu, J.-J. In situ immobilization of glucose oxidase in chitosan-gold nanoparticle hybrid film on Prussian blue modified electrode for high-sensitivity glucose detection. Electrochem. Commun. 2006, 8, 1468-1474. [CrossRef]

25. Albanese, D.; Sannini, A.; Malvano, F.; Pilloton, R.; Di Matteo, M. Optimisation of glucose biosensors based on sol-gel entrapment and Prussian blue-modified screen-printed electrodes for real food analysis. Food Anal. Methods 2013, 7, 1002-1008. [CrossRef]

26. Palod, P.A.; Singh, V. Improvement in glucose biosensing response of electrochemically grown polypyrrole nanotubes by incorporating crosslinked glucose oxidase. Mater. Sci. Eng. C 2015, 55, 420-430. [CrossRef] [PubMed]

27. Zhang, Y.; Liu, Y.; Chu, Z.; Shi, L.; Jin, W. Amperometric glucose biosensor based on direct assembly of Prussian blue film with ionic liquid-chitosan matrix assisted enzyme immobilization. Sens. Actuators B Chem. 2013, 176, 978-984. [CrossRef]

28. Lin, Y.; Hu, L.; Yin, L.; Guo, L. Electrochemical glucose biosensor with improved performance based on the use of glucose oxidase and Prussian blue incorporated into a thin film of self-polymerized dopamine. Sens. Actuatos B Chem. 2015, 210, 513-518. [CrossRef]

29. Li, L.; Sheng, Q.; Zheng, J.; Zhang, H. Facile and controllable preparation of glucose biosensor based on Prussian blue nanoparticles hybrid composites. Bioelectrochemistry 2008, 74, 170-175. [CrossRef] [PubMed]

30. Lad, U.; Kale, G.M.; Bryaskova, R. Glucose oxidase encapsulated polyvinyl alcohol-silica hybrid films for an electrochemical glucose sensing electrode. Anal. Chem. 2013, 85, 6349-6355. [CrossRef] [PubMed]

31. Ding, S.-N.; Dan, S.; Xue, H.; Zhu, D.; Cosnier, S. Glucose biosensor immobilized in alginatelayered double hydroxides hybrid membrane and its biosensing application. Anal. Sci. 2009, 25, 1421-1425. [CrossRef] [PubMed]

(C) 2016 by the authors; licensee MDPI, Basel, Switzerland. This article is an open access article distributed under the terms and conditions of the Creative Commons by Attribution (CC-BY) license (http://creativecommons.org/licenses/by/4.0/). 